\title{
Terra de índio x terra de branco: presença indígena e apropriação de terras em Guarulhos, sécs. XVII-XIX ${ }^{1}$
}

\author{
Marcia Eckert Miranda*
}

\begin{abstract}
MIRANDA, M.E. Terra de índio x terra de branco: presença indígena e apropriação de terras em Guarulhos, sécs. XVII-XIX R. Museu Arq. Etn., 26: 62-83, 2016.
\end{abstract}

Resumo: $\mathrm{O}$ texto discute a transformação da sociedade e do território guarulhenses, através da análise do processo de apropriação privada das terras do aldeamento original, pois a trajetória da apropriação de terras em Guarulhos é também a história do processo de desamortização das terras aldeamento de Nossa Senhora da Conceição, fator e consequência da redução progressiva da população indígena. As fontes documentais analisadas - a série "Registros de Terras da Província de São Paulo", produzida em obediência à Lei n. 601, de 18 de março de 1850, e o Livro Primeiro de Aforamentos de Guarulhos. Essas, ao lado da análise da legislação, permitiram traçar o processo de apropriação de terras pela elite guarulhense como uma consequência da progressiva desamortização das terras do antigo aldeamento ao longo do século XIX.

Palavras-chave: Guarulhos; História; Indígenas; Questão Agrária.

\section{Introdução}

E m 1845, o Coronel José Joaquim Machado de Oliveira, em seu relato sobre as aldeias da Província de São Paulo, afirmava:

Parecerá um phenomeno que no meio da devastação geral que pesava sobre os indios aldêados, quando o pessoal das aldêas soffria uma espantosa diminuição, uma houvesse que salva ao flagello commum, sobrepujando á males que para as outras foram inevitaveis, e sobranceira á idéa fixa, ao destino irrevogavel que pesou

1 A pesquisa documental no Arquivo Histórico Municipal de São Paulo (AHMSP) e no Arquivo do Estado de São Paulo (APESP) foi realizada pela bolsista Karina de Oliveira Oyakawa (Programa Capacitação - Treinamento Técnico/FAPESP) e a pesquisa no Arquivo Histórico Municipal de Guarulhos (AHMG) foi realizada pela bolsista Olivia Yumi Iwasaki da Silva (PIBIC/CNPq).

${ }^{*}$ ) Historiadora, Professora do Departamento de História da UNIFESP. sobre as outras, ostentasse direitos para ser excluida da desgraçada classe de aldêa: mas não o será a quem observar, que o sitio que foi designado para os Guarulhos continha em si mais elementos de riquezas ruraes do que os outros, e que para aproveital-as houve o bom senso de amalgamar a raça indigena com a europêa, e mesmo com a africana, cuja introducção em S. Paulo ai progredindo; derivando-se d'essa mistura as especies hybridas conhecidas com os nomes de mamelucos e caribocas. (Oliveira, 1867: 226-228).

Dessa forma, para Oliveira, o sucesso que justificou a elevação do aldeamento de Nossa Senhora da Conceição de Guarulhos à condição de freguesia, em 1685, estava relacionado à convergência de dois movimentos: a progressiva redução da população indígena através da miscigenação e a prosperidade econômica decorrente da riqueza natural da região. Mas, ao contrário do que o texto citado possa indicar, esses fatores traduzem-se em dois processos que estiveram, 
desde o século XVII, intimamente ligados: a exploração da mão de obra indígena e a apropriação e concentração da propriedade fundiária.

Este texto, no âmbito do projeto "Pesquisa e Inventário do Patrimônio Arqueológico de Guarulhos" (PIPAG), busca discutir a transformação da sociedade e do território guarulhenses, através da análise do processo de apropriação privada das terras do aldeamento original. Consideramos, como afirma Moreira (2002: 155), que no Brasil, houve uma forte "correlação entre questão indígena e política territorial”, subordinando a politica indianista aos interesses econômicos. Assim, trajetória da apropriação de terras em Guarulhos é a história do processo de desamortização das terras aldeamento de Nossa Senhora da Conceição, o qual foi fator e consequência da redução progressiva da população indígena (Moreira, 2013).

A pesquisa documental concentrou-se nas fontes textuais existentes em arquivos eclesiásticos e públicos em Guarulhos e na cidade de São Paulo. Os arquivos eclesiásticos, formados pelos registros produzidos pela Igreja Católica, são aqueles que custodiam os documentos mais antigos produzidos na localidade. Esses arquivos encontram-se dispersos em diversas instituições, como o Arquivo da Arquidiocese de São Paulo e o Arquivo da Diocese de Guarulhos e as suas paróquias. ${ }^{2}$ Os arquivos públicos pesquisados são o Arquivo Histórico Municipal de São Paulo (AHMSP), o Arquivo Histórico Municipal de Guarulhos (AHMG) e o Arquivo Público de São

2 É provável que os documentos mais antigos produzidos na região sejam aqueles produzidos pelos jesuítas a partir da segunda metade do século XVI; no entanto, é provável que esses registros tenham sido perdidos nos confrontos com os colonos ou recolhidos aos arquivos da Companhia de Jesus em Roma. Como, entre 1611 e 1685, o controle da vida religiosa e de diversos aspectos da vida civil da região do antigo aldeamento ficou sob a responsabilidade da Sé de São Paulo, muitos documentos relevantes para esse projeto de pesquisa encontram-se no acervo do Arquivo da Arquidiocese Metropolitana de São Paulo. Com a criação da Paróquia de Nossa Senhora da Conceição de Guarulhos em 1685 , os documentos por ela produzidos foram inicialmente custodiadas pela Diocese de São Paulo. Quando da criação, em 1962, da Diocese de Mogi das Cruzes, os registros de batismo, casamento e óbito dessa paróquia foram recolhidos para essa diocese, sendo transferidos, em 1981, para a recém-criada Diocese de Guarulhos.
Paulo (APESP). No AHMSP, foram consultados os Livros de Atas (1562-1669) e os Livros de Registros Gerais (1637-1709) da Câmara Municipal de São Paulo ${ }^{3}$ Os documentos produzidos e acumulados pelas autoridades da Capitania, da Província e do Estado de São foram pesquisados no Arquivo Público do Estado de São Paulo. Essas fontes permitem observar outros aspectos relativos à ocupação espacial, às edificações públicas, à demografia etc. Especificamente a série "Registros de Terras da Província de São Paulo" 4 traz 339 registros de terras na Freguesia de Guarulhos em obediência à Lei n. 601, de 18 de março de 1850, regulamentada pelo Decreto n. 1318, de 30 de janeiro de 1854 , que visava normatizar e registrar as propriedades existentes por título legal (sesmaria, compra, herança) ou por posse comprovada. Ainda que esses registros tivessem por objetivo legalizar a propriedade/ ocupação, acabaram sendo uma via de legitimação de uma determinada estrutura fundiária. Por fim, no AHMG, foram pesquisados os Livros de Atas da Câmara de Guarulhos e o Livro Primeiro de Aforamentos, os quais trazem noventa e nove registros de terrenos aforados nos anos de 1890-1891 e as transmissões de posse e/ou propriedades ocorridas até a década de 1930.

\section{A aldeia, as sesmarias e a freguesia}

A data de criação e a localização exata do aldeamento jesuítico de Nossa Senhora da Conceição de Guarulhos são temas controversos. ${ }^{5}$ A ação dos jesuítas entre esses índios deu-se a partir das últimas décadas do século XVI, mas,

3 Os Livros de Atas são registros formais dos temas e encaminhamentos definidos nas reuniões ordinárias e extraordinárias da Câmara; já os Livros de Registros Gerais trazem a cópia de provisões, ordens, alvarás e outros documentos recebidos ou emitidos pelas autoridades camarárias.

4 APESP, microfilme: v. 156; rolo RT08; código 17.04.040.

5 Sobre as diferentes interpretações acerca da data de fundação e das possíveis localizações do aldeamento e de sua Igreja, assim como sobre o qual padre jesuíta considerado seu fundador, ver Santos (2006), Romão e Noronha (1980), Sposito (2012) e Oliveira (2008). 
apesar das posições divergentes, sabe-se que esse aldeamento jesuítico já existia no início do século XVII, interpretação corroborada pelos registros da Câmara de São Paulo. ${ }^{6}$

Alguns historiadores enfatizam que a fundação desse aldeamento fora motivada pela necessidade do estabelecer um círculo protetor em torno da então vila de São Paulo, constituindo barreira à passagem de espanhóis e ao ataque de índios (Oliveira, 2008). ${ }^{7}$ Para além dessa função, a constituição do aldeamento jesuítico foi o marco inicial de um processo progressivo de ocupação luso-brasileira, motivado pela busca de riquezas constituídas pela posse de terras e de mão de obra nativa.

As terras do aldeamento de Guarulhos localizavam-se à margem direita do rio Tietê e foram concedidas como sesmaria pelo donatário da Capitania de São Vicente (Prezia, 2008). Mesmo assim, havia colonos estabelecidos em propriedades rurais localizadas às margens do aldeamento, ou mesmo nas invasões a ele, dedicados à lavoura do trigo e de outros alimentos, num processo que Monteiro (1994: 202) denominou de "depredação renovada nos aldeamentos”. A presença desses sítios e a necessidade de mão de obra eram geradoras de conflitos entre os colonos e a população aldeada. ${ }^{8}$

A retirada da aldeia de alçada religiosa

6 Ata da Câmara da Vila de São Paulo de 05/10/1608 (ARCHIVO MUNICIPAL DE SÃO PAULO. Actas da Camara da Villa de S. Paulo, 1596-1622. v. II. São Paulo: Duprat \& Cia, 1914: 222-223).

7 No século XVII, existiam, também em torno do núcleo central de São Paulo, os aldeamentos de Pinheiros, São Miguel, Barueri, Escada e Itaquaquecetuba (Santos, 2006).

8 Não apenas motivados pela ação predatória dos colonos explorando a mão de obra nativa, mas também a disputa pela terra era motivo de contendas entre os índios aldeados e os colonos. Foi o que ocorreu em 1623: em atendimento à representação dos indígenas do aldeamento de Nossa Senhora da Conceição, a Câmara da Vila de São Paulo deliberou que "fossem notificadas as pessoas que tivessem gado e criações nas terras dos ditos índios em termo de oito dias as despejassem e botassem fora as ditas criações com pena de seis mil reis aplicados para obras do conselho" (Acta da Câmara de São Paulo de 12/08/1623 - Archivo Municipal de S. Paulo. Actas da Camara da Villa de S. Paulo, 1623-1628. v. III. São Paulo: Duprat \& Cia, 1914: 47-48). também contribuiria para franquear o acesso às riquezas da região aos colonos. Em 1611, os aldeamentos de Guarulhos, de Pinheiros, de Barueri, de São Miguel, da Escada e de Peruíbe foram transferidos à jurisdição do Padroado Régio. Passavam, assim, a pertencer ao Rei de Portugal, cabendo à Câmara da Vila de São Paulo nomear os capitães laicos para administrá -las (Sposito, 2012). ${ }^{9}$ Nesta nova fase, a Câmara Municipal de São Paulo tornou-se o instrumento utilizado pelos paulistas para se apropriar das terras e da mão de obra indígena.

Nesse contexto, a descoberta e o início da exploração de ouro na região (Gama, 2009: 15), impuseram um ponto de inflexão ao processo de ocupação territorial e de apropriação de mão de obra. O ouro, descoberto em 1597 ou 1598, por Afonso Sardinha, o Velho, começou a ser efetivamente explorado no território do aldeamento de Nossa Senhora da Conceição a partir de 1612, por Geraldo Correia Sardinha (Oliveira, 2010), que para isso recebera uma carta de sesmaria às margens do Rio Baquirivu-Guaçu.

A concessão de sesmarias encontrava justificativa na existência de metais preciosos e nas condições dos requerentes para explorá-los, mas também na afirmação de que essas terras eram devolutas, não sendo exploradas pelos índios ou, até mesmo, que já estavam sendo ocupadas pelos requerentes há muitos anos (Gama, 2009; Monteiro, 1994). Pessoas como Mathias Lopes que, em 1660, afirmava ter "posse de um pedaço de terra dos índios Goaramimis há tempo de sete anos, pouco mais ou menos, onde tem seus currais e ranchos dos vaqueiros", dizia que seu pleito era justo, pois,

9 Mesmo que coubesse aos capitães da Aldeia, providos pela Câmara de São Paulo, reunir "os índios em sua aldeia e tirando-os das casas dos moradores donde estivessem" (Registro de uma provisão de 02/02/1661 passada pelo General Salvador Correia de Sá ao Capitão Antônio Lopes de Medeiros para Capitão da Aldeia de Nossa Senhora da Conceição dos Goarulhos - Archivo Municipal de São Paulo. Registro Geral da Câmara Municipal de São Paulo, 1661-1709. v. III. São Paulo: Typografia Piratininga, 1917: 13-15), administrando-os e governando-os, as constantes queixas demonstram que aumentaram a escravização e os maus-tratos aos indígenas dos aldeamentos; esses eram repartidos como escravos entre os moradores e submetidos a trabalhos forçados nas propriedades rurais e nas entradas para o sertão. 
estava estabelecido "sem fazer moléstia alguma aos ditos índios nem eles terem lavoura alguma na tal paragem". ${ }^{10}$

Segundo relação elaborada por Ranali (1986), muitos colonos obtiveram concessão de sesmarias e datas de terras no aldeamento ao longo do século XVII:

\section{5-11-1625}

Receberam sesmarias no aldeamento dos "guarus" na Tapera Grande, n. de ordem 25, Francisco Rodrigues, localizada no Campo do Sapateiro e Jarapebica, com 1.500 braças, junto ao Rio Juqueri e Miguel de Almeida, pela ordem n. 25, com 1.500 braças, na Conceição.

\section{0-4-1638}

Gregório Fagundes, pela ordem n. 30, recebe uma sesmaria de 1.500 braça, em Guarapiranga. Mais tarde, em 7-9-1641, recebia nova sesmaria, com 1.500 braças, pela ordem n. 69 , nos campos de Juqueri.

Na mesma data, sob n. de ordem 30 , Álvaro Rebello obtém sesmaria com 1.500 braças, em Guarapiranga, junto ao Rio Maquirubu (o nosso Baquiruvu).

Antônio Madureira consegue sesmaria, sob n. de ordem 30, com 3.000 braças, no sítio denominado Ibiratim.

[...]

6-3-1639

Recebe sesmaria, nas Minas do Geraldo, pela ordem n. 41, com 1.500 braças, Geraldo Mendes Peres e igual regalia é concedida a Baltazar Correia que obtém sesmaria com 1.500 braças, no mesmo local.

4-7-1639

A viúva Maria Rodrigues é beneficiada,

10 Traslado de petição de 04/01/1660 - Archivo Municipal de São Paulo. Registro Geral da Câmara Municipal de São Paulo, 1661-1709. v. III. São Paulo: Typografia Piratininga, 1917: 13-15. Ver também Traslado de uma carta de data de terras concedida a Henrique da Cunha Gago de 15/01/1661 (Archivo Municipal de São Paulo. Registro Geral da Câmara Municipal de São Paulo, 1661-1709. v. III. São Paulo: Typografia Piratininga, 1917: 12-13) e Registro do requerimento de Antônio da Cunha Cardoso de 18/04/1862 (Archivo Municipal de São Paulo. Registro Geral da Câmara Municipal de São Paulo, 1637-1660. v. II. São Paulo: Typographia Piratininga, 1917: 341-343) pela ordem n. 44, com uma sesmaria com 3.000 braças, no local denominado Guaramimins Tapera.

\section{1-7-1639}

Uma sesmaria com 3.000 braças é dada a Manuel António, na aldeia de Guarulhos, pela ordem n. 46 e, pela ordem de n. 25, com 1.500 braças, Miguel de Almeida consegue sesmaria no sítio do Chiqueiro.

\section{2-3-1640}

Recebe sesmaria, com 1.500 braças, no sítio denominado Sepetiba, território ocupado pelos índios guarús, Francisco Rodrigues Velho.

\section{8-8-1640}

Recebem sesmarias em território guarulhense, no local denominado Sepetiba, Sebastião Bicudo de Siqueira, com 500 e 1.500 braças, tudo conforme ordem n. 57 .

\section{7-9-1641}

Gaspar Sardinha da Silva consegue, pela ordem n. 61, sesmaria com 1.500 braças no Juqueri e, pela ordem n. 30, igual benefício é dado a Geraldo Correia que obtém sesmaria de 1.500 braças, nas Minas do Geraldo.

\section{9-12-1656}

Geraldo Correia Soares obtém, pela ordem n. 65, sesmaria com 1.500 braças, nos campos de Maqurubi.

[...]30-10-1666

Os oficiais da Real Câmara da Vila de São Paulo conferem, por carta a Francisco Poderozo, as terras dos índios não cultivadas, no Maqurubi.

\section{0-10-1667}

Manuel Rodrigues recebe, da Real Câmara da Vila de São Paulo, por carta, Terras de indios e devolutos mas há noves annos, na paragem chamada Maquirubú. (Ranali, 1986: $16,17,18)$.

No entanto, foi a partir da segunda metade do século XVII, que esse movimento ganhou maior impulso. Apesar das concessões preverem o pagamento do foro anual, a Câmara não fazia efetiva cobrança desse direito. Em 1682, pela ordem da Ouvidoria Geral, na sindicância de João da Rocha Pita, foram convocados os "mo- 
radores que estivessem lavrando terras de índios das aldeias de S.M. fossem à Câmara para lhes aforar", ou seja, para pagar o foro devido pela posse das terras do aldeamento que ocuparam com anuência da Câmara. ${ }^{11}$

A população indígena dos aldeamentos régios, frente ao avanço da apropriação das suas terras, apresentava uma redução expressiva, como expôs Salvador Correia de Sá ao Conselho Ultramarino em 1679. No caso de Guarulhos, dos 800 casais registrados em 1640, restariam apenas 70 (Monteiro, 1994: 204). Para além da miscigenação, como indicou Oliveira (1867: 226-8), a redução da população ameríndia estava relacionada à dispersão e à incorporação dos índios aldeados aos plantéis privados para o trabalho na mineração e na lavoura.

Já em 1660, após diligência dos oficiais da Câmara de São Paulo, registrava-se em ata que "... visitando a aldeia de Nossa Senhora da Conceição dos Guarulhos não achamos gentio nenhum nele". Inquiridos o Capitão do aldeamento, Estevão Ribeiro, e o seu Maioral, Diogo Martins, esses informaram que

... muitos deles andavam trabalhando por seu jornal em casa de alguns moradores, e outros estavam metidos por casa de alguns moradores, os quais os tinham sujeitos, machos e fêmeas, rapazes e raparigas, servindo-se deles como seus... (Registro Geral da Câmara Municipal de São Paulo, 1637-1660. Publicação official do Archivo Municipal de São Paulo. Vol. II. São Paulo: Typographia Piratininga, 1917: 581-2).

A fuga de indígenas para outras paragens também está registrada nessas atas, em pelo menos dois episódios. Nas duas ocasiões, a Câmara de São Paulo buscou fazer com que os indios retornassem a Nossa Senhora da Conceição, afastando os religiosos em torno dos quais buscavam proteção. Em 1665, o padre Mateus Nunes de Siqueira havia reunido um número ex-

11 Registro de 19/05/1682 - Archivo Municipal de São Paulo. Registro Geral da Câmara Municipal de São Paulo, 1637-1660. v. II. São Paulo: Typographia Piratininga, 1917: 340-41. pressivo de índios em um aldeamento junto ao rio Atibaia. A Câmara, no ano seguinte, determinou o afastamento do religioso e o que os índios fossem encaminhados para Nossa Senhora da Conceição. Três anos mais tarde, na mesma região de Atibaia, observou-se a ação do frei capuchinho Gabriel que reunira índios evadidos o mesmo aldeamento. ${ }^{12}$ A Câmara deliberou pela notificação do religioso, Frei Gabriel,

..., porquanto amotina os índios guarulhos de Sua Majestade que estavam situados na aldeia de Nossa Senhora da Conceição, e a seu senhor hão fugido muitos negros dos moradores, e se escrevesse ao dito padre o que tudo é em grande prejuízo deste povo e seus moradores (Ata de 25/05/1669. Actas da Camara da Villa de S. Paulo, 1653-1678. Publicação official do Archivo municipal de S. Paulo. V. VI. São Paulo: Typographia Piratininga, 1915: 164-5).

Esses fatos indicam que a população indígena remanescente no território do antigo aldeamento, reduzida pelas fugas e, provavelmente pela mortalidade elevada decorrente de doenças e da exploração intensa, encontrava-se dispersa, nos sítios dedicados à produção agrícola ou nas minas, sob regime de administração/escravidão, como demonstram os registros paroquiais de batizados e óbitos da Paróquia de Nossa Senhora da Conceição do século XVIII. ${ }^{13}$ Em 1772, segundo o padre José Vasconcelos, pároco da Igreja de Nossa Senhora da Conceição em ofício ao Governador da Capitania de São Paulo, a população indígena era formada por 64 indivíduos, dos quais, apenas 36 encontravam-se em Guarulhos. ${ }^{14}$

12 Actas da Camara da Villa de S. Paulo, 1656-1669. Publicação official do Archivo municipal de S. Paulo. Volume annexo ao v. VI. São Paulo: Typographia Piratininga, 1915: 160-162, 164-165, 428-429, 507-509; Monteiro, 1994: 199.

13 Arquivo Histórico da Cúria Diocesana de Guarulhos. Livro de registro de batismos, 1757-1770; livro de registro de óbitos, 1777-1813; livro de registro de óbitos, 1756-1779.

14 APESP. Secretaria do Governo. Seção Manuscritos. Aldeamento de índios, 1721-1810. Caixa 2, ordem 228. Maço 2; Pasta 1; 1721-1723; 20, documento 8 . 
Por outro lado, a existência de uma população numericamente expressiva, formada por brancos e pelo crescente número de escravos de origem africana que ingressavam nesse território, havia justificado, em 08 de maio de 1685, a elevação do aldeamento à condição de freguesia, quando a antiga capela foi transformada e paróquia (Ranali, 1986: 18). Esse fato tornou aquela região um núcleo populacional reconhecido pela Igreja, garantindo-se aos devotos da matriz e das suas capelas filiais o acesso aos sacramentos (batismo, casamento, extrema-unção/óbito, confissão) (Bueno, 2009).

Os dados sobre a população de Guarulhos são escassos, mas permitem avaliar seu crescimento. Segundo os resumos dos róis de confessos existentes, em 1797, havia na freguesia 598 fogos, ou seja, unidades domiciliares que abrangiam uma família estendida, formada do núcleo familiar, de agregados e escravos. A população com mais de sete anos de idade, e que, por isso, estava apta ao sacramento da confissão, totalizava 2.895 pessoas (Malaquias, 2012). Três anos mais tarde, o número de fogos subiu para 683. Considerando os róis de confessos disponíveis para os anos de 1797, 1798 e 1800, observa-se o crescimento da população local (fig. 1). No entanto, por se tratar de resumos, esses documentos nada não informam sobre a etnia da população.

José Arouche de Toledo Rendon, que havia sido nomeado Diretor Geral dos Índios da Capitania São Paulo, pelo Governador e Capitão General Antônio Manuel Mello Castro e Mendonça, escreveu as "Memória sobre as aldeias de índios da província de São Paulo, segundo as observações feitas no ano de 1798 - opinião do autor sobre a sua civilização" (1842). Nessas, Arrouche, ao avaliar a situação das aldeias criadas até então em São Paulo, afirmava que

Todas ellas existem, a excepção da dos Guarulhos, porque dando-se-lhe um parocho, que o fosse tambem dos brancos e mais povo morador dentro dos seus limites, veio a perder o nome de aldêa, ficando-lhe o da freguezia da Conceição dos Guarulhos; de sorte que hoje a maior parte do povo de S. Paulo ignora que aquella povoação, a qual já em 1800 tinha 3.696 habitantes, tivesse a sua origem em uma aldêa de Índios (3). (Rendon, 1842: 297).

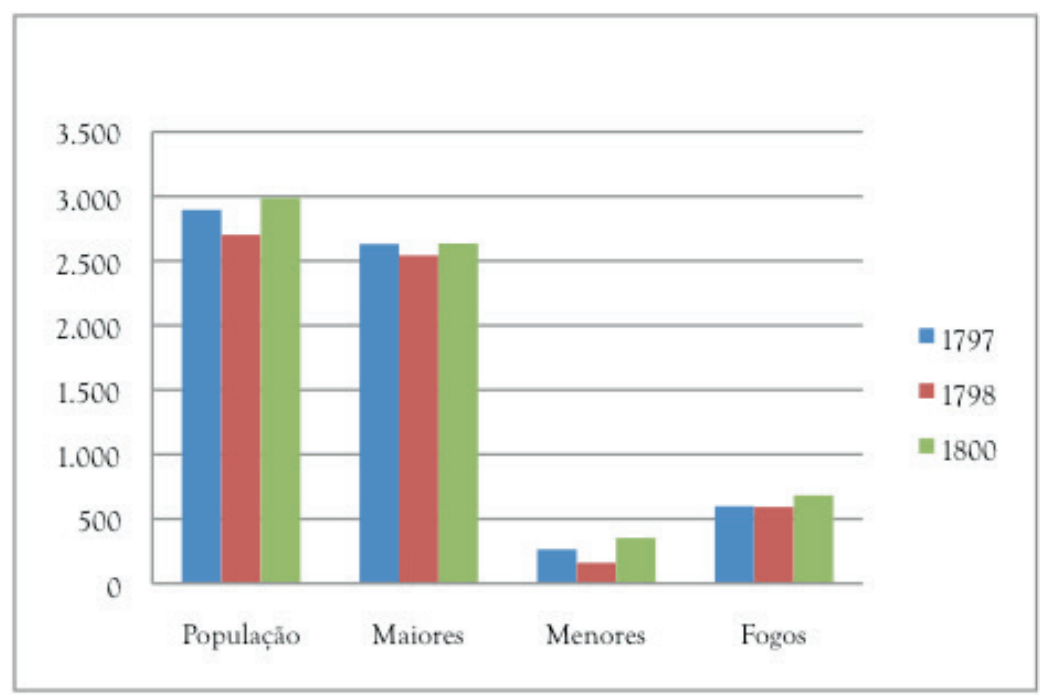

Fig. 1. População da Freguesia de N. Senhora da Conceição de Guarulhos. Fonte: Arquivo da Arquidiocese de São Paulo - Índice do rol de confessos de diversas freguesias - 1796-1846 - cota 5-2-9 - Róis de Confessos da Freguesia Conceição dos Guarulhos em 14 de julho de 1797, em 24 de julho de 1798 e em 24 de julho de 1808. 
Desse modo, a descoberta de ouro nas Gerais e a conversão da produção das grandes propriedades do planalto paulista para o abastecimento das minas estimularam o aprofundamento do perfil demográfico da região. Em contrapartida à crescente ausência ou invisibilidade dos indígenas dos registros eclesiásticos e governamentais a partir do século XIX, o processo de desamortização das terras do antigo aldeamento ganhou novo impulso.

\section{Lei de Terras: as terras do aldeamento transfor- madas em terras devolutas}

Com a independência do Brasil em 1822, as concessões de terras foram suspensas, iniciando um período caracterizado pela ausência de uma legislação de terras e oportunizando o avanço das apropriações sem qualquer alicerce legal (Moreira, 2002).

Ao final da primeira metade do século XIX, mais uma vez, a relação entre oferta de mão de obra e apropriação de terras articulavase, quando o governo passou a legislar sobre a questão agrária diante da iminente extinção da importação de escravos africanos e os imperativos ditados pela necessidade de desenvolver uma política de imigração de mão de obra livre..$^{15}$ Dessa forma, a Lei de Terras (Lei geral $n$. 601, de 18/09/1850), regulamentada pelo Decreto Imperial n. 1.318, de 30/01/1854, visava regularizar a propriedade fundiária, a partir da identificação, medição e registro das propriedades privadas e, por exclusão, identificar, medir e demarcar as terras devolutas. No entanto, essa lei e os instrumentos criados pelo decreto de 1854, acabaram por estabelecer as condições para a regularização de posses ilegais e por estimular o avanço da grilagem de terras.

O regulamento de 1854 determinava a realização do registro das propriedades, ${ }^{16}$ feitos pelos

15 Cabe observar que os processos de imigração estrangeira e colonização deram-se desvinculados da regulamentação da propriedade fundiária (Osório, 1996).

16 Também denominados na historiografia registros do vigário, registros paroquiais de terras, registros de terras (1996: 156-162). párocos de cada freguesia. Tratava-se de registrar as declarações feitas pelos possuidores de terras. Ainda que os assentamentos no livro de registro de terras sejam muito heterogêneos, esses trazem basicamente as seguintes informações: nome do proprietário, tipo de propriedade, bairro e/ou localidade, confrontações, extensão, forma de apropriação, se possui escritura ou outro documento que comprove o direito, data do registro. Essas são as informações que constam das 339 declarações transcritas pelo vigário João Vicente Valadão no registro da freguesia de Nossa Senhora de Guarulhos, ${ }^{17}$ como pode ser observado no primeiro assenta desse livro:

\section{Número 1}

Cópia da declaração que fazem para o registro geral $=$ do Jose Francisco, e Domingos Antonio Rodrigues de um sítio no Bairro do Taboão deste Distrito como abaixo se declara.

Nós abaixo assinados declaramos, que somos digo, que conjuntamente com diversos herdeiros somos senhores e possuidores [danificado] jardim [danificado] falescida Emerenciana Bueno de Toledo, de quem éramos escravos, e cuja posse gozamos a trinta anos mais ou menos, e que as suas divisas são as seguintes $=$ começando no ribeirão de Taboão, seguindo a estrada até dar em um valo velho, e seguindo o valo até dar em um Caraguathá, e descendo o Caraguathá abaixo até sair no campo, e seguindo o mesmo Garaguathá até dar no açude do Tanque Velho, e descendo o ribeirão abaixo até desaguar no Baquiruvú, e rodando o Baquiruvú abaixo até encontrar com o mesmo ribeirão de Taboão. Freguesia da Conceição dos Guarulhos dezenove de agosto de mil oitocentos cinquenta e quatro. Geraldo Jose Francisco $=$ Arrogo de Domingos Antonio Rodrigues por não saber escrever Jose Rodrigues da Cunha Junior $=$ nada mais se continha em dita declaração, em cujos exemplares lancei a seguinte nota $=$ número

17 As observações e conclusões que se seguem foram sistematizadas a partir desses registros através do Quadro I, no Anexo Relatório PIPAG (www2.unifesp.br/centros/arqueologia) 
primeiro. Apresentado no dia dezenove de agosto de mil oitocentos e cinquenta e quatro. João Vicenth Valladão = e naquele que fica arquivado vai lançada a data do registro que é a mesma supra. Freguesia de Nossa Senhora da Conceição dos Guarulhos 19 de agosto de 1854 .

O vigário João Vicenth Valladão

Pg. $1 \$ 500$ rs.

[a] Valladão.

(Arquivo Público do Estado de São Paulo - "Registros de Terras da Província de São Paulo", vol. 156 - Microfilme: vol. 156; rolo RT08; código 17.04.040).

Esses registros seriam remetidos à Diretoria Geral das Terras Púbicas e serviriam de base para a elaboração de registro geral de terras para o país. Ainda que o ato de registrar não implicasse a legalização da posse, a sua existência acabou sendo explorada na Justiça por posseiros e proprietários para sancionar situações de fato, seja a posse de um terreno sem instrumento legal ou a extrapolação da área concedida em carta de data ou sesmaria (Osório, 1996).

Como salienta Osório (1996), além da regulamentação das propriedades fundiárias havidas por concessão da Coroa, a demarcação de terras devolutas e definição das formas de acesso a essas eram questões essenciais e pontos de tensão no que tange aos direitos daqueles estabelecidos por posse. As terras devolutas deveriam ser destinadas à colonização indígena e estrangeira, à Marinha, à venda e a novos povoados (Osório, 1996).

No artigo $3^{\circ}$ da Lei de Terras, definia-se o que eram terras devolutas:

Art. 3o São terras devolutas:

$\S 1^{\circ}$ As que não se acharem applicadas a algum uso publico nacional, provincial, ou municipal.

$\S 2 \circ$ As que não se acharem no dominio particular por qualquer titulo legitimo, nem forem havidas por sesmarias e outras concessões do Governo Geral ou Provincial, não incursas em commisso por falta do cumprimento das condições de medição, confirmação e cultura.

$\S 3^{\circ}$ As que não se acharem dadas por sesmarias, ou outras concessões do Governo, que, apezar de incursas em commisso, forem revalidadas por esta Lei (Lei n. 601, de 1 de Setembro de 1850 Dispõe sobre as terras devolutas do Império. Disponivel em http://www.planalto. gov.br/ccivil_03/Leis/L0601-1850.htm. Acesso em: 18 fev. 2015). ${ }^{18}$

Sendo as terras devolutas definidas por exclusão, era crucial estabelecer quais espaços encontravam-se ocupados, abrindo-se o caminho para o reconhecimento das propriedades de terrenos recebidos por aforamento, sesmaria e por simples apossamento.

Com relação à terra indígena, em acordo com o Regulamento das Missões de 1845, que indicava a necessidade de "catequese e civilização” dessa população, a Lei de 1850 atribuía ao governo a possibilidade de lhes reservar terras; mas, essa população perdia sua condição de proprietária de suas terras, passando a depender da tutela do Estado (Osório, 1996; Moreira, 2002). Dessa forma, essas determinações atuavam no sentido de "transformar o índio em trabalhador (mão de obra para as fazendas) e, ao mesmo tempo, tornar disponíveis as suas terras" para a apropriação privada (Osório, 1996: 171). Com esse propósito, a Decisão n. 92, de 21/10/1850, determinou que fossem incorporadas "aos próprios nacionais as terras de descendentes de índios que estivessem 'confundidas' na massa da população civilizada” (Moreira, 2002: 163), tornando essas propriedades em terras devolutas.

Dez anos mais tarde, a Lei n. 1.144, de 27 de setembro de 1860 , permitiu que as terras pertencentes a aldeias indígenas consideradas "abandonadas" fossem aforadas pelos governos provinciais.

Art. 11. O Governo fica desde já autorizando:

[...] § 8० Para aforar ou vender, na conformidade da Lei no 601 de 18 de Setembro de 1850, os terrenos pertencentes ás antigas Missões e Aldêas dos Indios, que estiverem

18 Para uma discussão dos diferentes sentidos dessa palavra empregados na lei, ver Osório (1996: 156-162). 
abandonados, cedendo todavia a parte que julgar sufficiente para a cultura dos que nelles ainda permanecerem, e os requererem (Lei $n^{\circ}$ 1.114, de 27 de Setembro de 1860, fixando a despeza e orçando a receita para o exercicio de 1861 - 1862. Disponível em: <http://www2.camara.leg.br/legin/ fed/lei/1824-1899/lei-1114-27-setembro1860-556118-publicacaooriginal-75787-pl. html>. Acesso: 12 jan. 2015).

A essa determinação somava-se, na Província de São Paulo, a Resolução Oficial n. 29, de 19 de maio de 1862 , que autorizou aquele governo a extinguir antigos aldeamentos (Moreira, 2013). Em 1875, o Decreto n. 2672, de 20 de outubro, facultou a venda das terras já aforadas nas áreas das aldeias extintas (Coleção de Leis do Império do Brasil - 1875: 154, v. 1, pt I). Assim, por diversos instrumentos legais, progressivamente, o governo imperial ampliou o poder das autoridades provinciais e municipais para extinguir os aldeamentos remanescentes e vender/aforar suas terras (Verazani, 2009). O mecanismo adotado seguia um padrão: "os aldeamentos eram considerados abandonados e nesse caso os terrenos caíam na condição de devolutos (aviso de 20 de maio de 1869 , por exemplo) e, sendo assim, o governo podia vendê-los, aforá-los, ou legitimá -los na posse particular" (Osório, 1996: 171). ${ }^{19}$ Dessa forma, a política fundiária em relação às terras indígenas tinha um sentido claro, transformar em devolutas as terras em mãos de indígenas ou de aldeamentos, tornando-as passíveis de apropriação privada.

O interessante no caso de Guarulhos é que, nos 339 assentamentos lançados pelo Padre João Vicente Valadão nos registros paroquiais de terras nos anos de 1854 a 1856 não há menção textual às terras da antiga sesmaria pertencente ao Aldeamento de Nossa Senhora da Conceição de Guarulhos. Difícil determinar

19 "Inúmeros atos posteriores do governo imperial mandaram extinguir os aldeamentos indigenas e venderem-se suas respectivas terra ou dar-lhes outro destino (ordem n. 44 de 21 de janeiro de 1856, avisos de 21 de abril de 1857 e de 21 de julho de 1858 , aviso de 27 de setembro de 1860 , decreto n. 2.672 de outubro de 1875 etc.)" (Osório, 1996: 171). quando o aldeamento foi declarado ou considerado extinto, já que no início do século XVIII, mesmo após a criação da freguesia, há referências a esse aldeamento e à sua população..$^{20} \mathrm{No}$ entanto, uma análise mais detalhada dos dados constantes nesses registros desvenda a intensa apropriação de terras nas localidades onde, no passado, concentrara-se a população indígena.

Assim, os registros de terras revelam informações que permitem visualizar um retrato da ocupação do território Guarulhos, e em especial, as localidades onde a presença indígena era mais intensa, e de sua estrutura fundiária. As denominações vagas utilizadas para identificar do tipo de propriedade (sítio, terreno, tapera, fazenda, cercado, campo) pouco ajudam a inferir a sua dimensão ou a atividade econômica ali desenvolvida. A extensão do terreno somente consta em 102 registros (30\% das propriedades) e as confrontações declaradas são imprecisas, utilizando-se como marcos delimitadores referências a acidentes geográficos, "elementos paisagísticos, ou simplesmente por uma cerca, que a qualquer momento poderia ser alterada" (Gama, 2009: 24-5). Avaliação dessas dimensões é extremamente difícil, seja pelo uso de unidades de medida antigas (léguas e braças), seja pela inexatidão da informação, muitas vezes omitindo o comprimento e a largura. $\mathrm{Na}$ Figura 02 a seguir, aparecem as referências às dimensões mais frequentes, correspondendo a cerca de $56 \%$ das propriedades com dimensão declarada. ${ }^{21}$

Os 339 registros identificam 375 propriedades nas mãos de 326 pessoas, dos quais 73 detêm a propriedade com outros sócios. Como

20 Ver Arquivo Público do Estado de São Paulo. Secretaria do Governo. Seção Manuscritos. Aldeamento de índios, 1721-1810. Caixa 2, ordem 228. Maço 2; Pasta 1; 1721-1723; documento 13; ofício circular do Governador da Capitania, Conde de Sarzedas [Antônio Luiz de Távora], de 27 de janeiro de 1733, ao padre Antonio Cazaddo Villas Boas, vigário de Nazareth, ao padre Salvador Cardozo, vigário de São João de Atibaya, e ao padre Estanisláo de Moraes, vigário da Freguesia da Conceição [Guarulhos] (Archivo, 1902: 27).

21 Considerando que uma braça quadrada equivalia a 2,20 metros x 2,20 metros ou 4,84 metros quadrados e que uma légua de sesmaria equivalia a 6.600 metros x 6.600 metros ou 43.560.000 metros quadrados (Costa, s.d). 
demonstra a Tabela 1 , dos proprietários identificados, a maioria $(80,37 \%)$ possuía apenas um lote, havendo um número relativamente pequeno de proprietários, cerca de $19 \%$, com mais de dois lotes.

Das 375 propriedades registradas, $68 \%$ (255) identificaram o bairro em que se localizavam. Cabe, no entanto, observar a imprecisão do termo "bairro". Conforme Monteiro (1994: 1990), no Período Colonial, o "bairro representava pouco mais que um mero apêndice rural da vila, com a finalidade de proporcionar uma estrutura organizativa capaz de atender algumas das necessidades coletivas de seus moradores", constituídos de "constelações de sítios rurais", com alguma articulação entre si, mas que cresciam em torno de grandes unidades produtivas. Já no século XIX, nos registros pesquisados, dada a dispersão de denominações utilizadas, é difícil determinar se esse termo refere-se a uma divisão administrativa instituída ou à prática cotidiana que conferiu uma identidade a determinado território. Por isso, optamos por conservar os termos "bairro" e "localidade", tal como aparecem nos assentamentos. Os declarantes muitas vezes informavam apenas o bairro, mas em 21 assentos, além do bairro, também foi informado o nome da localidade.

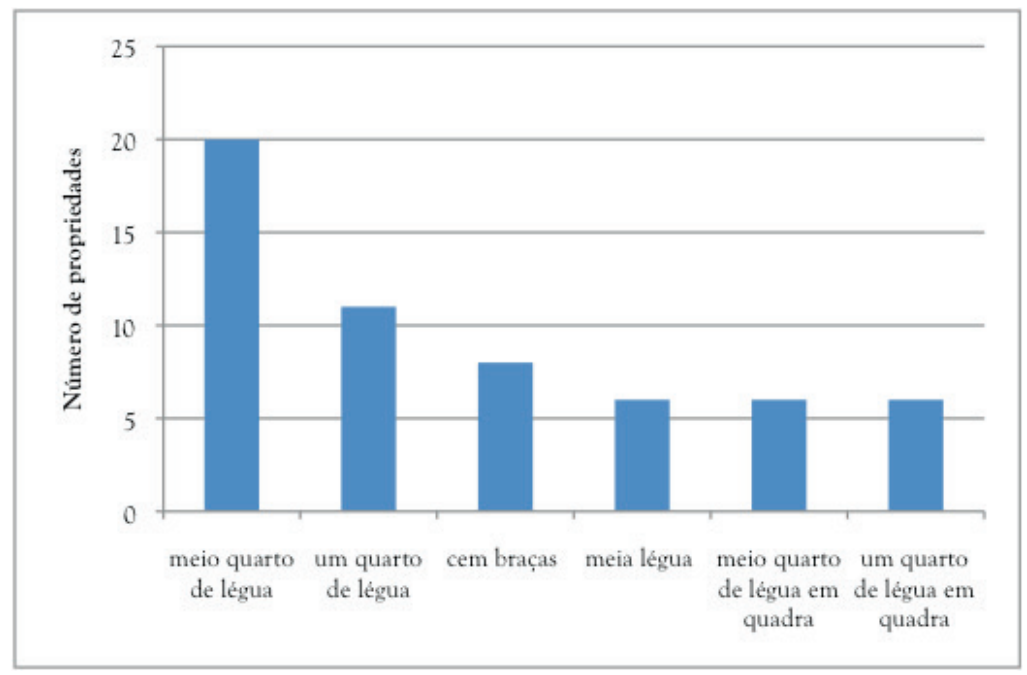

Fig. 2. Extensão dos lotes - Registro de Terras Guarulhos 1854 a 1856. Fonte: Arquivo Público do Estado de São Paulo - "Registros de Terras da Província de São Paulo" v. 156 - Microfilme: v. 156; rolo RT08; código 17.04.040.

\begin{tabular}{|c|c|c|}
\hline N. de lotes & N. de proprietários & \% do n. de proprietários \\
\hline 4 & 6 & 1,84 \\
3 & 11 & 3,37 \\
2 & 47 & 14,42 \\
1 & 262 & 80,37 \\
\hline Total & 326 & 100,00 \\
\hline
\end{tabular}

Tabela 1: Registros paroquiais de terras da freguesia de Nossa Senhora da Conceição de Guarulhos Propriedades e proprietários de terras - 1854-1856. Fonte: Arquivo Público do Estado de São Paulo - "Registros de Terras da Província de São Paulo” v. 156 -Microfilme: v. 156; rolo RT08; código 17.04.040. 
Dentre as várias denominações de bairros e/ou localidades declaradas, $18,43 \%$ estavam no bairro das Lavras; $14,51 \%$ no "bairro de São Miguel"; 11,98\% no bairro de "Itaverava" e 9\% no bairro do Bonsucesso (fig. 3). As demais propriedades distribuíam-se com frequência igual ou inferior a $5 \%$ entre outros 37 locais com denominações variadas. Essa informação chama a atenção por duas questões: a predominância de propriedades declaradas nos bairros onde se desenvolvera no passado a mineração (52,92\%) e a localização do "bairro de São Miguel". Essa última questão ganha importância, pois, segundo declararam os possuidores de sítios e terrenos na freguesia, $21,53 \%$ (73) eram de "foros da extinta Aldeia de São Miguel".

A existência de outro aldeamento nas terras da freguesia de Guarulhos ou a localização do bairro de São Miguel são questões controversas na historiografia. Segundo Santos (2006: 47-8), havia, localizado nos atuais bairro dos Pimentas e distrito de Itaim, outro aldeamento denominado São Miguel, distinto daquele que originou o distrito paulistano de São Miguel Paulista. Para esse autor, as terras desse aldeamento foram aforadas a partir da segunda metade do século XIX e originaram, no século seguinte, o "Bairro de São Miguel”. A interpretação de Santos (2006) não é inédita, mas apoiada em outros autores como João Ranali (2002) e Romão e Noronha
(1980). Romão e Noronha apresentam explicações distintas para a existência do aldeamento de São Miguel e para o bairro do mesmo nome. Afirmam que, no passado, existiu outra aldeia no território de Guarulhos, localizada no atual bairro dos Pimentas (Romão e Noronha, 1980: 36). Em outro momento, os autores sustentam que, quando da emancipação de Guarulhos da cidade de São Paulo, fazia parte de seu território a freguesia da Penha, da qual integrava a aldeia de São Miguel, "que aparecia exatamente com essa denominação em documentos de 1881" (Romão e Noronha, 1980: 125). Desse modo, infere-se que, segundo esses autores, as referências a esse "bairro" em Guarulhos datariam das últimas décadas do século XIX, interpretação também defendida por Santos.

No entanto, como demonstram os registros de terras da década de 1850 , as referências ao bairro e à extinta aldeia de São Miguel já estavam presentes, o que indica a antiguidade dessas denominações e o efetivo pertencimento do território ou parte deste à freguesia de Nossa Senhora da Conceição. Essa posição é corroborada pela interpretação de John Monteiro (1994), segundo a qual não havia dois aldeamentos com a mesma denominação. Para esse autor, o bairro de São Miguel surgiu da expropriação das terras do aldeamento indígena do mesmo nome. Esse aldeamento recebera, em

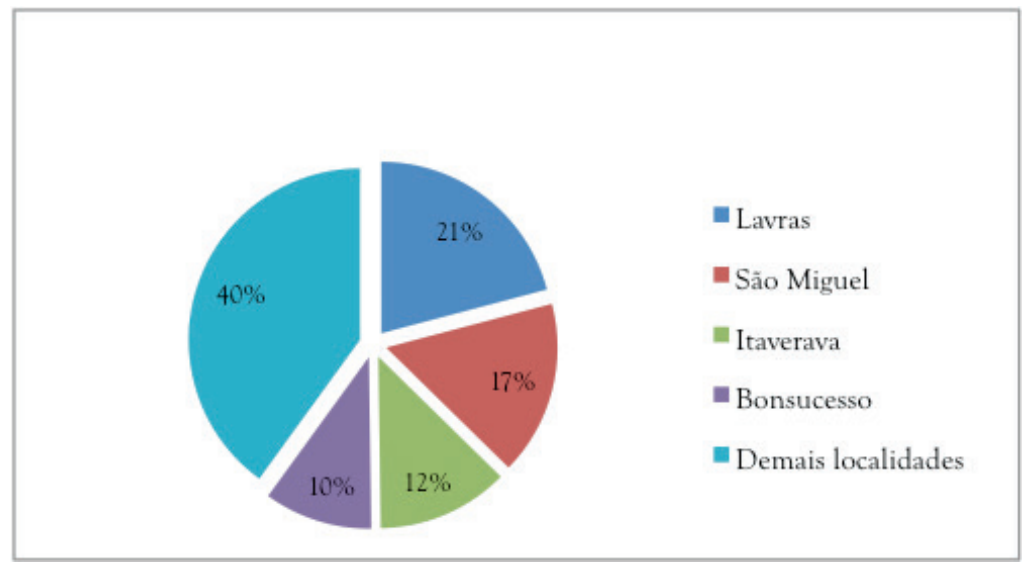

Fig. 3. Registros paroquiais de terras - Guarulhos 1854-1856. Distribuição \% dos lotes por bairro. Fonte: Tabela 2 - Arquivo Público do Estado de São Paulo - "Registros de Terras da Província de São Paulo” v. 156 - Microfilme: v.156; rolo RT08; código 17.04.040. 
1580, a sesmaria de Ururaí, a qual abrangia as duas margens do Tietê:

O aldeamento em si ficava na margem sul, circundado, porém, de terras consideradas parte do bairro de Caaguçu. $\mathrm{O}$ que aparece na lista do donativo como o bairro de São Miguel incluía, basicamente, as pequenas propriedades ao redor da capela de Bonsucesso, a qual pertencia à fazenda de Francisco Cubas (Monteiro, 1994: 205-206).

Desse modo, as referências ao aldeamento de São Miguel não fazem menção a outro aldeamento, mas a uma região que, originariamente, pertencia à sesmaria concedida àquele aldeamento. A Capela do Bonsucesso, que se localizaria nesse território, fora fundada por Francisco Cubas em 1670 (Oliveira, 2010), em sua propriedade, na qual explorava um grande plantel de índios (Monteiro, 1994). ${ }^{22}$ Em torno dessa grande propriedade, diversas outras surgiram em consequência do apossamento simples ou do aforamento, ${ }^{23}$ sendo os atuais bairros de Lavras e
Bonsucesso os mais antigos de Guarulhos, cuja ocupação foi estimulada em decorrência da lavra do ouro e da exploração da mão de obra local (Gama, 2009). Dessa forma, a região onde se concentravam as posses/propriedades declaradas entre 1854 e 1856 localizavam-se na zona leste do atual município de Guarulhos, das margens do rio Tietê, próximo ao atual bairro dos Pimentas à "Itaberava" (Itaberaba) próximo à Santa Isabel.

Quanto às formas de apropriação da terra, observa-se o predomínio de três modalidades: compra $(32,53 \%)$, herança $(26,67 \%)$ e o aforamento (16,27\%) (fig. 4). A posse foi citada

22 Segundo Monteiro (1994: 191), as capelas tiveram papel relevante no desenvolvimento dos bairros rurais de São Paulo, geralmente associadas "à presença de um número considerável de índios". Sobre a capela e a Festa de Nossa Senhora do Bonsucesso, ver Pinheiro (2004)

23 Interpretação corroborada pela identificação de dois sítios/ terrenos que, segundo declaração do proprietário/possuidor situavam-se no bairro de São Miguel, na localidade do Morro Vermelho, localizado entre os atuais bairros dos Pimentas e do Bonsucesso (registros 2018 e 303, Quadro 1, no anexo Relatório PIPAG - www2.unifesp.br/centros/arqueologia).

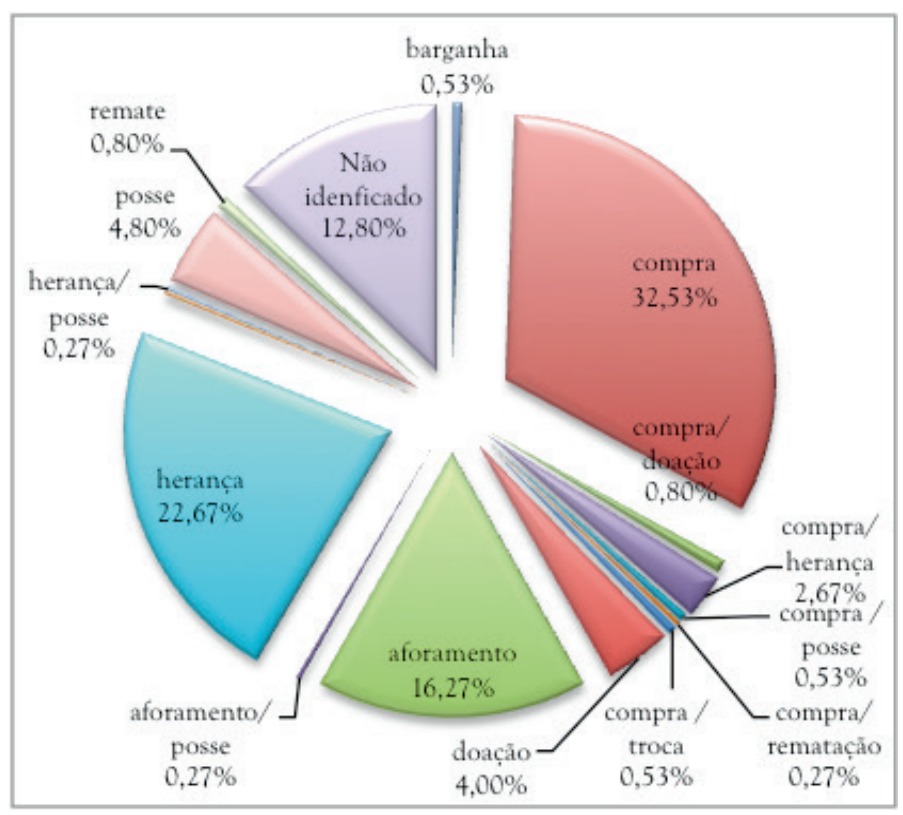

Fig. 4. Origem da Propriedade - Freguesia de Guarulhos 1854-1856. Fonte: Tabela 3, no Anexo - Arquivo Público do Estado de São Paulo "Registros de Terras da Província de São Paulo" v. 156 -Microfilme: v. 156; rolo RT08; código 17.04.040. 
como forma de apropriação, isoladamente ou associada à herança, aforamento ou compra, em apenas $5,87 \%$ dos lotes declarados. No entanto, cabe observar que em 48 registros (12,8\%) não houve a declaração da forma de apropriação do terreno e, nos casos em que houve a declaração, poucos informaram dispor de títulos originais ou dos documentos de compra e venda. Nesses casos, a origem da propriedade é incerta, se doação de sesmaria ou data de chãos ou negociação de um terreno aforado.

Desse modo, observa-se o intenso processo de apropriação de terras atingindo diferentes áreas do antigo aldeamento. Esse movimento deu-se de forma mais intensa na região leste da freguesia, concentrada nas antigas terras próximas onde ocorrera a exploração do ouro e onde as grandes propriedades, possivelmente havidas por doação e posse, foram em sua maior parte legadas por herança ou por venda.

\section{Final do século XIX: Guarulhos, municipali- dade e a retomada dos aforamentos}

Nas últimas décadas do século XIX, a emancipação de Guarulhos trouxe a possibilidade, através da Câmara Municipal, da elite local passar a dirigir o processo de legalização/apropriação das terras "da extinta aldeia de Indios neste Municipio” (Arquivo Histórico Municipal de Guarulhos - Livro primeiro de aforamentos da vila de Guarulhos - 1890-1891). ${ }^{24}$

Em 14 de fevereiro de 1880, fora apresentado à Assembleia Provincial o projeto n. 21, assinado pelos deputados Reis França, Oliveira Braga, Campos Toledo, C. Gavião (Barão do Pinhal), Luiz Carlos, João de Melo e Ferreira Braga, propondo a elevação de Guarulhos à categoria de vila. Dentre os autores dessa

24 Em 88 dos 99 registros de aforamentos, essa expressão estava presente (Quadro 2, no Anexo Relatório PIPAG - www2. unifesp.br/centros/arqueologia).

25 Disponível em <http://www.al.sp.gov.br/repositorio/ legislacao/lei/1880/lei-34-24.03.1880.html>. Acesso em: 25 nov. 2014.

26 "Art. 8o É o Governo autorisado:

[...] $3^{\circ}$ A transferir á Illma. Camara Municipal do Rio de Janeiro proposta estavam João Álvares Siqueira Bueno e o Padre João Vicente Valadão, responsável pela paróquia de Nossa Senhora da Conceição entre os anos de 1843 a 1889 e pela elaboração dos registros de terras do início da década de 1850 (Ranali, 1986; Romão, Noronha, 1980).

Aprovado o projeto, Guarulhos foi elevada à condição de vila, desligando-se do município de São Paulo pela Lei n. 34, de 24/03/1880. ${ }^{25}$ Seu território abrangia as freguesias da Conceição, da Penha e do Juqueri, o que, segundo Viana (2011), decorria de um acordo entre as elites das três localidades em torno de um objetivo comum. A Câmara Municipal foi instalada em sessão solene no dia 21 de janeiro de 1881 . Nessa oportunidade, além da posse dos membros da primeira legislatura, foi eleito como seu Presidente e Intendente Municipal, o vereador Capitão Joaquim Francisco de Paula Rebello, cargo que ocupou ininterruptamente o final do II Reinado (Ranali, 1986: 26). Rebello, 1856, havia declarado ser possuidor de três sítios localizados nos atuais bairros de Picanço e Cabuçu, havidos por compra e por herança.

Além do controle sobre a arrecadação de tributos e da delimitação das despesas municipais e o poder de nomear funcionários para diversos postos, a Câmara Municipal possuía também, conforme o Decreto de 2.672, de 20 de outubro de 1875 , o direito de alienar ou utilizar as terras indígenas para a fundação de vilas e povoações. Poderes esses que foram ampliados pela lei do orçamento n. 3.348, de 20 de outubro de 1887, que legou aos municípios os terrenos das extintas aldeias que se localizavam em seus territórios, cabendo-lhes as receitas dessas alienações e as despesas decorrentes da medição e demarcação (Verazani, 2009). ${ }^{26}$ Ou seja, a emancipação envolvia uma série de poderes, o que justificavam da associação das três fregue-

o direito de aforar os terrenos accrescidos aos de marinhas existentes no Municipio Neutro, e ás Camaras Municipaes das Provincias os de marinhas e accrescidos nos respectivos municipios, passando a pertencer á receita das mesmas corporações a renda que dahi provier, e correndo por sua conta as despezas necessarias para medição, demarcação e avaliação dos mesmos terrenos, observadas as disposições do Decreto n. 4105 de 22 de Fevereiro de 1868.

Os fóros dos terrenos das extinctas aldeias de indios, que não 
sias em torno desse objetivo; no entanto, não tardou para que as disputas surgissem, levando à defesa de projetos emancipacionistas por parte das freguesias da Penha e do Juqueri.

As relações foram tensas e:

... essa aliança acabou se mostrando muito frágil, e o conflito de interesses, além da pressão de grupos rivais, como no caso da Penha, minaram as relações entre os grupos das três antigas freguesias. No abaixo -assinado da Penha podemos ver os nomes de alguns membros da primeira legislatura da câmara, e a mesma coisa se repete no abaixo-assinado feito por Juqueri. No caso de Juqueri, os dois últimos anos em que fez parte do território de Guarulhos foram provavelmente bastante tensos, com os vereadores de Juqueri chegando a boicotar as sessões na Câmara durante cinco meses em 1888, nos meses de maio, junho, agosto, setembro e novembro, e seis meses em 1889 , de fevereiro a julho (Viana, 2011: 39).

Num curto espaço de tempo, o município de Guarulhos perdeu o território de ambas as freguesias. Pela Lei Provincial n. 71, de 03 de maio de 1886, freguesia de Penha de França foi anexada à capital da Província e pela Lei Provincial n. 66, de 27 de março de 1889, foi criado o município de Juqueri (Ranali, 1986: 36).

Mesmo com jurisdição sobre um território reduzido, a Câmara Municipal de Guarulhos

$>$ forem remidos nos termos do art. $1^{\circ}, \S 1^{\circ}$, da Lei n. 2672 de 20 de Outubro de 1875 , passarão a pertencer aos municipios onde existirem taes terrenos; correndo por conta dos mesmos as despezas da respectiva medição, demarcação e avaliação. Os terrenos que não se acharem nas condições do $\S 3^{\circ}$ da Resolução n. 2672 de 20 de Outubro de 1875, e não forem pelo Ministerio da Agricultura empregados nos termos da Lei de 18 de Setembro de 1850, e os terrenos das extinctas aldeias de indios serão do mesmo modo transferidos ás Provincias em que os houver. Nenhum arrendamento ou aforamento de quaesquer terrenos, nem a renovação dos actuaes arrendamentos, poderá effectuar-se sinão em hasta publica a quem melhores condições offerecer; sendo applicadas aos proprios desta natureza as disposições do Decreto n. 4105 de 22 de Fevereiro de 1868; e considerando-se nullas quaesquer concessões em contrario desta disposição;..." (Disponível em http://www2.camara.leg.br/ legin/fed/lei/1824-1899/lei-3348-20-outubro-1887-542992-publicacao original-52680-pl.html. Acesso em: 20 fev. 2015) exerceu seu poder, aforando as terras da extinta aldeia, o que, segundo Gama (2009: 24), demonstra que "a acumulação imobiliária tem seu início no momento em que a Câmara Municipal de Guarulhos é autorizada a registrar" esses contratos.

A realização de aforamentos de terrenos pela Câmara teve início em 1891, em um novo contexto econômico e social. Desde 1850 até a abolição da escravidão (1888), a composição da riqueza sofreu uma metamorfose no Brasil. Se até então a "propriedade [da terra] não caracterizava riqueza em si mesma” (Gama, 2009: 18), mas uma função da associação da terra ao trabalho escravo, as transformações nas relações de trabalho impuseram um novo significado à propriedade plena da terra, uma das formas assumida pelo capital. A exploração do trabalho livre tornou-se condição necessária para a geração da renda da terra no processo de acumulação capitalista. Dessa forma, a terra tornou-se, ao mesmo tempo, mercadoria, capital e estoque de riqueza.

Os registros de aforamentos realizados na década de 1890 são distintos daqueles resultantes do regulamento da Lei de Terras de 1854. Trata-se do registro de um contrato firmado entre a municipalidade e o foreiro, no qual constam as seguintes informações: o nome do foreiro, o tipo de propriedade, o bairro e/ou localidade, as confrontações, o valor do foro anual devido à Câmara, data do assentamento e assinatura do escrivão:

Jezuino Jozé Rodrigues, aforou hum terreno da extinta aldeia de Índios neste Municipio as divizas são o seguinte principia em hum Córrego divizando com os foros do Sr. Felisbino Jozé Rogurigues sobre Córrego asima athe o fim athe o espigão sobe espigão asima athe dar na diviza do Cardozo daí desce divizando com o mesmo Cardozo athe o vallo daí segue o vallo athe o córrego daí desse córrego abaixo athe o Cannal segue o Cannal asima athe a onde principiou, Villa da Conceição dos Guarulhos 30 de $10 \mathrm{br}^{\circ}$ de 1890. Paga foro annual de 3000 mil réis (Arquivo Histórico Municipal de Guarulhos - Livro primeiro de aforamentos da vila de Guarulhos 1890-1891, fl. 32). 
Em nenhum dos registros realizados nos anos de 1890 e 1891, é informado se o foreiro já ocupava e produzia no lote, pois essa não era condição ou impedimento para a realização do contrato, embora se saiba que nos anos seguintes à Lei de Terras e no decorrer da República Velha (1889-1930), o processo de apropriação privada das terras públicas, especialmente por simples ocupação, foi intenso e viabilizado pela flexibilização dos prazos estipulados pela legislação para a legitimação da posse nos diversos estados brasileiros (Silva, 2008).

No entanto, a ausência de informações das dimensões dos lotes, num primeiro momento, causa estranheza, mas gerava uma ambiguidade e incerteza que poderia ser utilizada pelos foreiros para aumentar seus lotes. Como nos registros anteriores, as confrontações dos terrenos eram identificadas por acidentes geográficos naturais (morros, rios, lagos etc.), mas, principalmente, acidentes artificiais (casas, porteiras, poços etc.) e elementos paisagísticos (árvores, moitas de caraguatá etc.) (Gama, 2009: 24-5).

Entre os anos de 1890 e 1891, foi aberto o "Livro primeiro de aforamentos da vila de Guarulhos", contendo 99 aforamentos, beneficiando 113 pessoas. Dentre essas, 61\% eram foreiros individuais, sendo que o restante tinha um ou mais sócios (fig. 5).

Dois foreiros receberam dois lotes (sendo um lote em sociedade), doze foreiros receberam dois lotes (sendo cinco lotes com sócios) e os demais noventa e nove foreiros receberam apenas um lote (dos quais, trinta e oito em sociedade) (fig. 6).

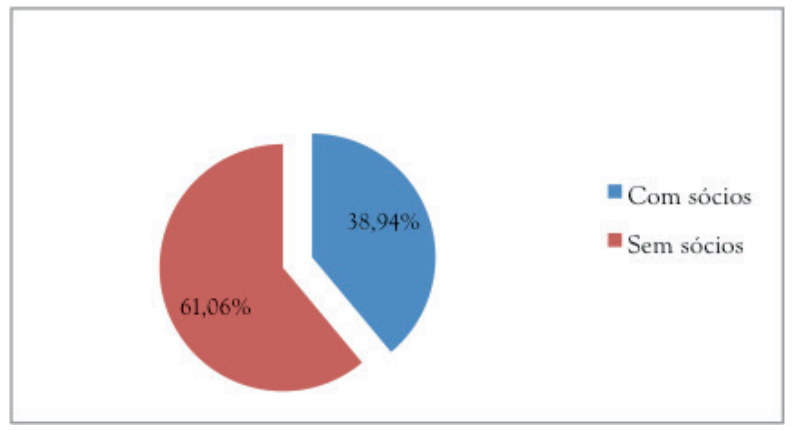

Fig. 5. Aforamentos com e sem sócios Guarulhos - 1890-1891. Fonte: Quadro 2. Arquivo Histórico Municipal de Guarulhos Livro primeiro de aforamentos da vila de Guarulhos (1890-1891).

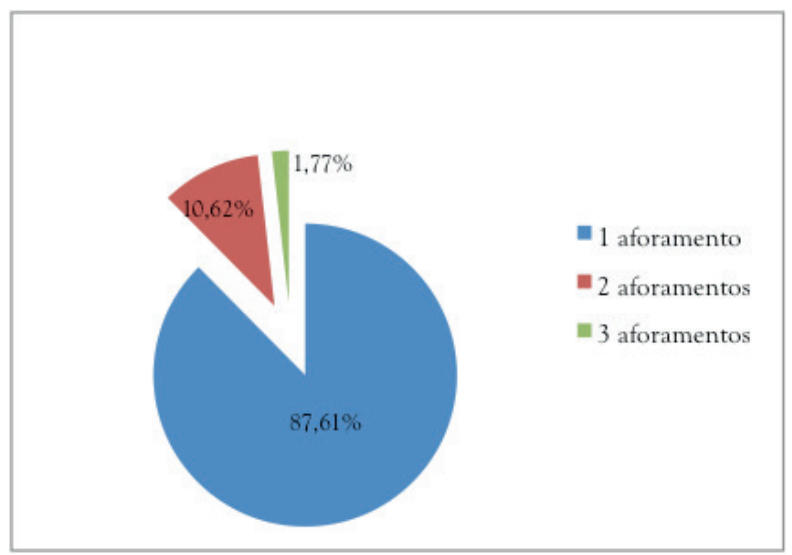

Fig. 6. Número de aforamentos por beneficiários Guarulhos - 18901891. Fonte: Quadro 2. Arquivo Histórico Municipal de Guarulhos -Livro primeiro de aforamentos da vila de Guarulhos (1890-1891). 
A despeito da ausência de informações sobre as dimensões dos terrenos, os dados permitem-nos inferir que a distribuição dos terrenos aforados pela Câmara Municipal de Guarulhos estabeleceu a descentralização da propriedade. No entanto, a observação dos dados posteriores, acrescidos a cada assentamento, relativos a remissões, heranças e transações por venda dos lotes, o panorama sofreu alterações. No caso do terreno aforado a Jezuino José Rodrigures, citado antes, foram acrescentadas logo abaixo do assentamento as seguintes alterações:

Pagou em 10 de Janeiro de 1891 o exercício de 1890 e 1891 a quantia de 2000 mil reis dois mil reis.

Fica transferido este fora acima Ao Senhor Abilio Soares a folhas 10 e 11 do $4^{\circ}$ Livro de Contractos de aforamentos.

Ao Snr. Abilo Soares.

Fica Transferido este foro a Benedicto Pires de Freitas por transferencia que fez Dona Joaquina Maria da Conceição como herdeira do seu legitimo marido o fallecido Jezuino José Rodrigues.

Vila da Conceição dos Guarulhos, 15 de Outubro de 1894.

[a] O Secretario, Pedro Miguel da Silva

Pagou o Snr ${ }^{a}$ D. Maria Viuva do fallecido Benedicto Pires de Freitas os fôros atrazados presentes os exercicios de 1894 , 1895, 1896, 1897, 1898 e 1899 (Arquivo Histórico Municipal de Guarulhos - Livro primeiro de aforamentos da vila de Guarulhos (1890-1891, fl. 32).

Dos 127 nomes surgidos das negociações posteriores ao aforamento original, 103 detinham um lote, vinte possuíam dois lotes, um possuía três lotes e três proprietários tinham quatro lotes (fig. 7). Estes últimos eram o Coronel Abílio Soares, Felício Marcondes Munhoz e Raimundo Rodrigues Caraça. O nome de Abílio Soares aparece nas transferências/ remissão de quatro lotes (folhas 6, 4, 31 e 32). $\mathrm{Fez}$ fortuna no comércio, passando a investir em terras em diversas localidades do Estado de São Paulo, possuindo várias propriedades em Guarulhos. Seu assassinato, em 24 de agosto de 1919, teria sido motivado por disputas de terras (Ranali, 1986: 79). Felício Marcondes Munhoz era morador do Bonsucesso e foi um dos quatro intendentes municipais escolhidos pelo Governo Provisório republicano em 1891, período no qual recebera dois aforamentos (folhas $48 \mathrm{e}$ 49) (Gama, 2009: 23 - 24). Foi vereador eleito e presidiu a Câmara em 1894 (Romão e Noronha, 1980). No início do século XX, envolveu-se nas compra e remissão de outros quatro lotes (folhas $37,40,45$ e 70 ).

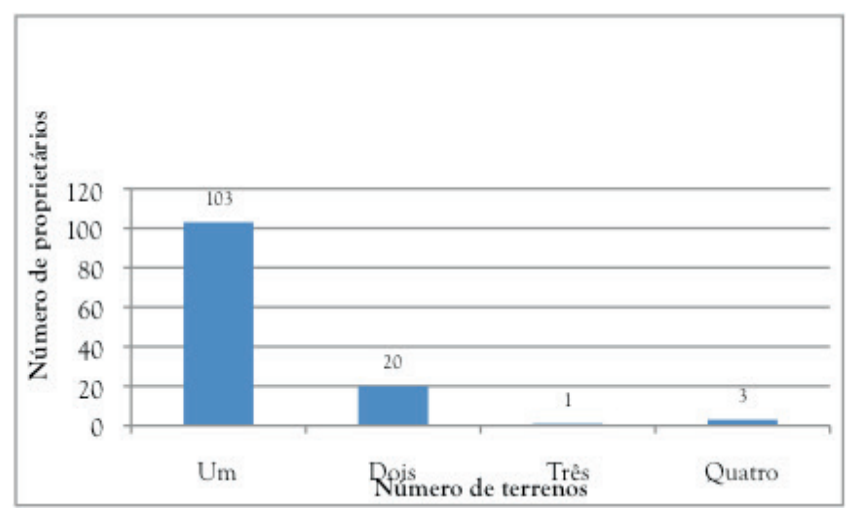

Fig. 7. Transferências e vendas. Proprietário/foreiros por número de terrenos Guarulhos - 1890-1891. Fonte: Quadro 2. Arquivo Histórico Municipal de Guarulhos - Livro primeiro de aforamentos da vila de Guarulhos (1890-1891). 
Os aforamentos envolviam o compromisso ao pagamento de foros anuais à Câmara, sendo uma das suas fontes de receitas patrimoniais. A receita de um ano de aforamentos, considerando os valores registrados, totalizaria $492 \$ 200$ réis, correspondendo a $12,77 \%$ da receita total do município no segundo semestre de 1882 (Ranali, 1980: 30). Como pode ser observado na figura 8 , os valores dos foros eram extremamente baixos e apresentam uma grande variância, possivelmente em função da extensão dos lotes. Os registros demonstram que os pagamentos dos foros foram realizados, na maior parte dos casos, até a remissão dos aforamentos.

Com relação à localização, em apenas quatro registros, não foi localizada a expressão "da extinta aldeia de Indios neste Municipio”. Possivelmente, essa informação corroborava o direito da Câmara de aforar esses terrenos que pela lei seriam devolutos. Os bairros e as localidades identificadas demonstram a dispersão desses lotes no território guarulhense com a predominância de três bairros: Bonsucesso (35\% dos lotes), São Miguel (19\%) e Lavras (9\%) (fig. 9).Analisando

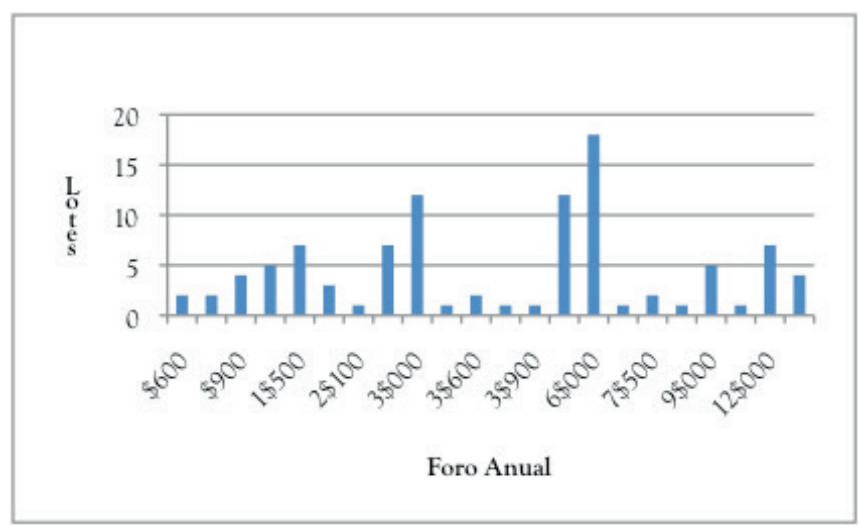

Fig. 8. Aforamentos de Guarulhos 1890-1891. Propriedades por foro anual (mil-réis). Fonte: Quadro 2; Arquivo Histórico Municipal de Guarulhos - Livro primeiro de aforamentos da vila de Guarulhos (1890-1891).

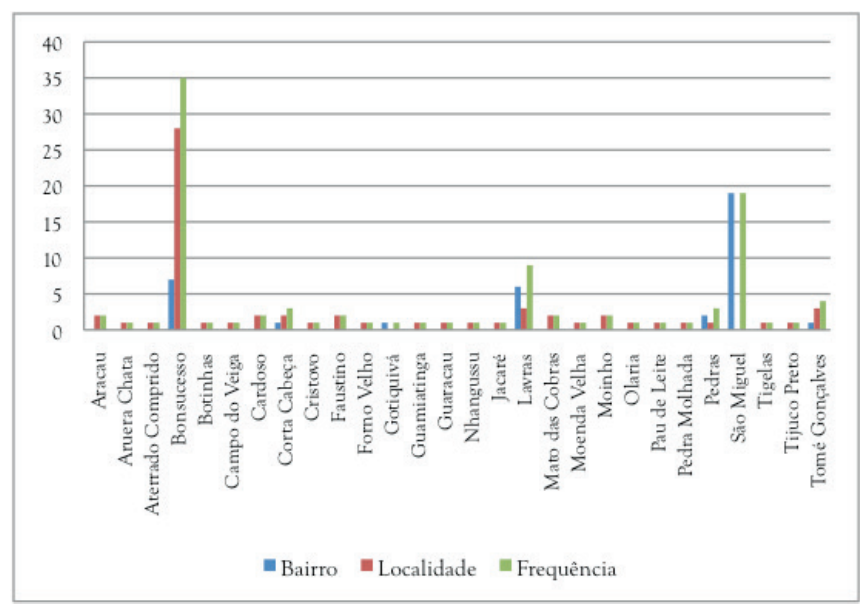

Fig. 9. Localidades e bairros dos lotes aforados Guarulhos - 1890-1891. Fonte: Quadro 2. Arquivo Histórico Municipal de Guarulhos - Livro primeiro de aforamentos da vila de Guarulhos (1890-1891). 
esses registros de aforamento, Gama (2009) concluiu que o processo de concentração fundiária em Guarulhos ganhara impulso quando a Câmara Municipal passou a exercer sua atribuição de aforar as antigas terras indígenas. A partir das evidências dos registros, afirma:

Os Termos de Contrato de Aforamento demonstram a intencionalidade de garantir a acumulação fundiária, numa caracterização evidente da terra como elementos de constituição da riqueza. Por outro lado, nota-se que o espaço de interesse concentrase fundamentalmente nas antigas áreas de mineração. (Gama, 2009: 25).

Dessa forma, os aforamentos consolidaram a "legalidade da propriedade privada no município de Guarulhos, formalizando uma elite fundiária detentora de grandes glebas de terras nas áreas de assentamento de aldeias indígenas" (Gama, 2009: 26). Característico desse período é a direção imposta pela elite local, agora desvinculada do controle paulistano e expressa através da Câmara Municipal, utilizando os mecanismos legais de que dispunha para atender aos seus interesses. As terras indígenas, consideradas pela legislação como devolutas, serão utilizadas para aumentar a riqueza e o poder dessa elite, através do progressivo estabelecimento do monopólio da terra.

Relativamente rápido, o processo de apropriação das terras em Guarulhos foi uma das faces do processo de desaparecimento/acobertamento da população indígena ali existente. A legislação de terras e a ação da elite local através da Câmara Municipal foram instrumentos que viabilizaram a desamortização das antigas terras indígenas, lançando no esquecimento a presença indígena e o seu aldeamento em Guarulhos.

MIRANDA, M.E. Indians land $\mathrm{x}$ white man's land: indigenous presence and land appropriation in Guarulhos, $16^{\text {th }}-18^{\text {th }}$ centuries. R. Museu Arq. Etn., 26: 62-83, 2016.

\begin{abstract}
The paper discusses the transformation of Guarulhos' territory and society, by analyzing the process of land appropriation of the original settlement, for the trajectory of land appropriation in Guarulhos is also the story of the process of land confiscation of the Our Lady of Conception settlement, factor and a consequence of the progressive reduction of the indigenous population. The analyzed documentary sources - the "Land Records of the São Paulo Province" series, produced in compliance with Law n. 601 of March 18, 1850, and the First Book of aforamentos (fueros) of Guarulhos. These, along with the analysis of the legislation, allowed for the process of land appropriation by the guarulhense elite to be traced as a result of the progressive confiscation of the old settlement lands throughout the nineteenth century.
\end{abstract}

Keywords: Agrarian issue; Guarulhos; History; Indigenous. 


\section{Referências Bibliográficas}

Fontes:

Arquivo da Arquidiocese de São Paulo (AASP)

Annuario Ecclesiastico da Archidiocese de S. Paulo no 1 1912-1913

Indice do Rol de confessos diversas freguesias (1796-1846), cota 5-2-9

Livro de Tombo da Catedral da Sé (1554 a 1895)

Mapas das Parochias Archidiocese de São Paulo (1911)

Arquivo Histórico Municipal de Guarulhos (AHMG)

Livro de Atas da Câmara Municipal de Guarulhos (1881-1889)

Livro primeiro de aforamentos da vila de Guarulhos (1890-1891)

Arquivo Histórico Municipal de São Paulo (AHMSP)

São Paulo. Actas da Camara da Villa de S. Paulo, 1562-1596. Publicação official do Archivo municipal de S. Paulo. v. I. São Paulo: Duprat \& Cia, 1914.

São Paulo. Actas da Camara da Villa de S. Paulo, 1596-1622. Publicação official do Archivo municipal de S. Paulo. v. II. São Paulo: Duprat \& Cia, 1914.

São Paulo. Actas da Camara da Villa de S. Paulo, 1653-1678. Publicação official do Archivo municipal de S. Paulo. v. VI. São Paulo: Typographia Piratininga, 1915.

São Paulo. Actas da Camara da Villa de S. Paulo, 1640-1652. Publicação official do Archivo municipal de S. Paulo. v. V. São Paulo: Typographia Piratininga, 1915.
São Paulo. Actas da Camara da Villa de S. Paulo, 1656-1669. Publicação official do Archivo municipal de S. Paulo. Volume annexo ao v. VI. São Paulo: Typographia Piratininga, 1915.

São Paulo. Registro Geral da Câmara Municipal de São Paulo, 1637-1660. Publicação official do Archivo Municipal de São Paulo. v. II. São Paulo: Typographia Piratininga, 1917.

São Paulo. Registro Geral da Câmara Municipal de São Paulo, 1661-1709. Publicação official do Archivo Municipal de São Paulo. v. III. São Paulo: Typografia Piratininga, 1917.

Arquivo Público do Estado de São Paulo (APESP)

\section{ARCHIVO DO ESTADO DE SÃO PAULO.}

Publicação official de Documentos interessantes para a História e costumes de S. Paulo. v. XLI. Correspondência do Conde de Sarzedas aos vigários, 1732-1736. S. Paulo: Typographia Andrade \& Mello, 1902.

Secretaria do Governo. Seção Manuscritos. Aldeamento de índios, 1721-1810. Caixa 2, ordem 228, documento 7 .

Ofícios ao Presidente e outras autoridades provinciais. Viver em São Paulo: O poder e o cotidiano. Projeto "Memórias Paulistanas: preservação e disponibilização de ofícios diversos de São Paulo (18221919)". Ministério da Justiça - Fundo de Defesa dos Direitos Difusos (FDD). Disponível em: http://www.arquivoestado.sp.gov.br/viver/poder.php. Acesso em: 03 ago. 2013

Fundo Secretaria de Governo. Série Maços de População de São Paulo. Viver em São Paulo. Rescenciando a População. Disponível em: http://www.arquivoestado.sp.gov.br/ viver/recenseando.php. 
Terra de índio x terra de branco: presença indígena e apropriação de terras em Guarulhos, sécs. XVII-XIX

Viver em São Paulo: Memória da Escravidão. Projeto Preservação da memória da escravidão em São Paulo no século XIX, apoiado pelo Programa de Apoio ao Desenvolvimento dos Arquivos Ibero-americanos (ADAI). Disponível em: http://www.arquivoestado. sp.gov.br/viver/escravos.php. Acesso em: 27 jun. 2013.

APESP. Secretaria do Governo. Seção Manuscritos. Aldeamento de índios, 1721-1810. Caixa 2, ordem 228.

Registros de Terras da Província de São Paulo. v. 156 - Microfilme: v. 156; rolo RT08; código 17.04.040.

Arquivo histórico ultramarino (Lisboa, Portugal)

Projeto Resgate (Arquivo Histórico Ultramarino - Lisboa - Portugal)

AHU-São Paulo-MGouveia, cx. 1, doc. 14.AHU_ACL_CU_023-01, Cx. 1, D. 14

AHU-São Paulo-MGouveia, cx. 25, doc. 2395. AHU_ACL_CU_023-01, Cx. 25, D. 2395

\section{LIVROS E ARTIGOS}

Arroyo, L. 1966. Igrejas de São Paulo. São Paulo: Editora Nacional.

Brasil. Arquivo Nacional. 2005. Dicionário brasileiro de terminologia arquivística. Rio de Janeiro: Arquivo Nacional.

Bueno, B.P.S. 2009. Dilatação dos confins: caminhos, vilas e cidades na formação da Capitania de São Paulo (1532-1822). Anais do Museu Paulista. São Paulo, n. ser. v. 14 (2): 251-294.

Costa, I. Pesos e Medidas no Período Colonial Brasileiro: denominações e relações. s.d. Disponível em: <http://www.ipeadata.gov.br/doc/ Pesos\%20e\%20medidas\%20no\%20periodo\%20colonial\%20brasileiro.pdf>. Acesso em: 12 mar. 2015.
Gama, N.C. de O. 2009. O processo de conformação da periferia urbana no município de Guarulhos: loteamentos periféricos como (re) produção de novas espacialidades e lugar de reprodução da força de trabalho. Dissertação (Mestrado em Geografia Humana). Faculdade de Filosofia, Letras e Ciências Humanas. Universidade de São Paulo.

Guarulhos, Prefeitura Municipal. 2007. Projeto de Qualificação do Centro de Guarulhos. Guarulhos, PMG / São Paulo, Mendes da Rocha Arquitetos Associados.

Malaquias, C. de O. 2012. Fogos mineiros na passagem do século XVIII ao XIX: uma aplicação da "tipologia plurifuncional de domicílios" à freguesia de São José do Rio das Mortes. Anais do XV Seminário de Economia Mineira. Diamantina, 2012. Disponível em: <http://web.cedeplar.ufmg.br/cedeplar/seminarios/ecn/ecn-mineira/2012/ arquivos/FOGOS\%20MINEIROS\%20 NA\%20PASSAGEM\%20DO\%20S\%C3\%89CULO\%20XVIII\%20AO\%20XIX.pdf>. Acesso em: 25 out. 2013.

Monteiro, J. M. 1994. Negros da Terra: Índios e bandeirantes nas origens de São Paulo. São Paulo: Cia. das Letras.

Moreira, V.M.L. 2013. Notas sobre a "cidanização" e desamortização das terras de índios no Império brasileiro. Anais do XVII Simpósio Nacional da ANPUH, Natal. Disponível em: <http://www.snh2013.anpuh.org/ resources/anais/27/1364667711_ARQUIVO_TextoSimposioANPUH2013.pdf>. Acesso em: 13 jan. 2015.

Moreira, V. M. L. 2002. Terras Indígenas do Espírito Santo sob o Regime Territorial de 1850. Revista Brasileira de História. São Paulo, v. 22 (43): 153-169.

Muller, D.P. 1978. Ensaio d'um quadro estatístico da província de São Paulo: ordenado pelas leis municipais de 11 de abril de 1836 e 10 de março de 1837. 3. ed. facsimilada. Introdução de 
Honório de Sylos. São Paulo: Governo do Estado. (Coleção paulística, v.11).

Nazzari, M. 2000. Da escravidão à liberdade: a transição de índio administrado para vassalo independente em São Paulo Colonial. In: SILVA, Maria Beatriz Nizza da. Brasil: colonização e escravidão. Rio de Janeiro: Nova Fronteira: 28-44.

Noronha, A. de V. 1960. Guarulhos Cidade Simbolo. Guarulhos, s/e.

Oliveira, A.F. de. et. al. 2010. Revelando a História do Bonsucesso e Região: nossa cidade, nossos bairros. São Paulo: Noovha América.

Oliveira, E.S. et. al. 2008. Guarulhos: espaço de muitos povos. 2 ed. São Paulo: Noovha America.

Oliveira, E.S. 2013. Guarulhos. História, cultura e meio ambiente. Circuitos e roteiros de visitas. s. ed. s. 1.

Oliveira, J.J.M. de. 1867. Notícia racionda sobre as aldeas de índios da Provincia de S. Paulo, desde o seu começo até a actualidade. Revista Trimestral de História e Geografia ou Jornal do Instituto Historico e Geographico Brasileiro. 2. ed. Rio de Janeiro: Typographia de João Ignacio da Silva, 4 (13): 204-62.

Osório, L.S. 1996. Terras devolutas e latifúndio. Efeitos da lei de 1850. Campinas: Ed. UNICAMP.

Pieta, E. 1992. Revirando a História de Guarulhos. São Paulo: Inca, 1992.

Pinheiro, J. E. de M. 2008. Ciclo do ouro em Guarulhos. In: Omar, Elmi El Hage (Org.). Guarulhos tem História: questões sobre História Natural, Social e Cultural. São Paulo: Ananda: 74-87.

Pinheiro, M. 2004. Santuário de Nossa Senhora do Bonsucesso: uma longa tradição profana. Dissertação (Mestrado) - Faculdade de
Ciências e Letras de Assis. Universidade Estadual Paulista, Assis.

Prézia, A.B. 2008. Maromomi, os primeiros habitantes de Guarulhos: da perambulação ao aldeamento. In: Omar, Elmi El Hage (Org.). Guarulhos tem História: questões sobre História Natural, Social e Cultural. São Paulo: Ananda: 59-73.

Ranalli, J. 2002. Repaginando a História. Guarulhos: Soge - Faculdades Integradas de Guarulhos.

Ranalli, J. 2002. Onomástica Indígena dos Logradouros Públicos de uma Grande Cidade. São Paulo, GEVC.

Ranalli, J. 1986. Cronologia Guarulhense. v. 2. São Paulo: Guarulhos, s/e.

Rendon, J.A. de T. 1842. Memória sobre as aldeias de índios da província de São Paulo, segundo as observações feitas no ano de 1798 - opinião do autor sobre a sua civilização. Revista Trimestral do Instituto Geográfico Brasileiro, Rio de Janeiro: Typ. De João Ignacio da Silva, t. 4: 295-317.

Romão, G.J.R.; Noronha, A. de V. Guarulhos. Edição histórica comemorativa do I Centenário de Emancipação Polícia de Guarulhos (1880-1980). Guarulhos: Orefeutyra Municipal.

Santana, A.S. de et al. 2014. Em torno da ferrovia e da rodovia: o processo de industrialização de Guarulhos e seu patrimônio industrial (1910-1960). In: Borges, Augusto César Maurício; Omar, Elmi El Hage (Orgs.). Signos e significados em Guarulhos: identidade, urbanização, exclusão. São Paulo: Navegar: 91-110.

Santos, C.J.F. dos. 2006. Identidade urbana e globalização. A formação dos múltiplos territórios em Guarulhos/SP. São Paulo: Annablume; Guarulhos: Sindicato dos Professores de Guarulhos. 
São Paulo. Governo do Estado. 2001. Memória Urbana, A grande São Paulo até 1940. São Paulo: Editora Emplasa / Arquivo do Estado.

Silva, L.O. 2008. Terras devolutas e latifúndio. Efeitos da lei de 1850. 2. ed. Campinas: Ed. Unicamp.

Sposito, F. 2012. Santos, heróis ou demônios? Sobre as relações entre indios, jesuitas e colonizadores na América Meridional (São Paulo e Paraguai/Rio da Prata, séculos XVI-VII). Tese (Doutorado em História). São Paulo: Faculdade de Filosofia, Letras e Ciências Humanas. Universidade de São Paulo, 2012.

Verazani, K.S. 2009. Assenhorar-se de terras indigenas: Barueri - sécs. XVI-XIX. Dissertação (Mestrado em História Econômica). Faculdade de Filosofia, Letras e Ciências Humanas. Universidade de São Paulo, 2009.

Viana, G.F.P. 2011. Tensões e embates na configuração do território de Guarulhos, 1860-1889. Trabalho de Conclusão (Graduação). Escola de Filosofia, Letras e Ciências Humanas. Universidade Federal de São Paulo, 2011.
Vide, S.M. da. 2010. Constituições primeiras do Arcebispado da Bahia. São Paulo: EDUSP.

Zanon, D. 2012. Bispos de São Paulo - as diretrizes da Igreja no século XVIII. São Paulo: Annablume/Fapesp.

Sites:

Guarulhos, Prefeitura Municipal. História da cidade. Disponível em <http://www.guarulhos.sp.gov.br>. Acesso em: 25 maio 2013.

Guia da Penha. A padroeira de Nossa Senhora do Rosário dos Homens Pretos. Disponível em <www.guiadapenha.com.br/HistoriadaPenha/05_PADROEIRANSROSARIO. htm>. Acesso em: 25 maio 2013.

Movimento Guarulhos tem História. Disponível em <http://www.guarulhostemhistoria. com.br>. Acesso em: 12 jul. 2013. São Paulo, Prefeitura Municipal. Capela de Nossa Senhora do Rosário completa 204 anos..Disponível em <http://www. prefeitura.sp.gov.br/portal/a_cidade/noticias/index.php? $\mathrm{p}=10327>$. Acesso em: 25 maio 2013. 